\title{
A review of the financial impact of production diseases in poultry production systems
}

Article

Accepted Version

Jones, P. J., Niemi, J., Christensen, J.-P., Tranter, R. B. and Bennett, R. M. (2019) A review of the financial impact of production diseases in poultry production systems. Animal Production Science, 59 (9). pp. 1585-1597. ISSN 1836-0939 doi: https://doi.org/10.1071/AN18281 Available at https://centaur.reading.ac.uk/78999/

It is advisable to refer to the publisher's version if you intend to cite from the work. See Guidance on citing.

To link to this article DOI: http://dx.doi.org/10.1071/AN18281

Publisher: CSIRO Publishing

All outputs in CentAUR are protected by Intellectual Property Rights law, including copyright law. Copyright and IPR is retained by the creators or other copyright holders. Terms and conditions for use of this material are defined in the End User Agreement.

www.reading.ac.uk/centaur 
Central Archive at the University of Reading

Reading's research outputs online 


\section{A review of the financial impact of production diseases in poultry production}

2 systems

3

4 Jones $^{1 \#}$, P.J., Niemi², J., Christensen ${ }^{3}$, J-P., Tranter $^{1}$, R.B. and Bennett ${ }^{1}$, R.M.

5

6 (\#) Corresponding author: Tel: +44 (0)118 3788186; Email: p.j.jones@reading.ac.uk

7 (1) School of Agriculture, Policy and Development, University of Reading, PO Box 237,

8 Whiteknight, Reading, RG6 6AR, England.

9 (2) Natural Resources Institute Finland (Luke), Bioeconomy and Environment Unit, 10 Kampusranta 9, FI-60320 Seinäjoki, FINLAND.

11 (3) Department of Veterinary and Animal Sciences, Faculty of Health \& Medical Sciences, 12 University of Copenhagen, Stigbøjlen 4, 1870 Frederiksberg C, Denmark. 


\section{Abstract}

Whilst the academic literature widely asserts that production diseases have a significant financial impact on poultry propduction, these claims are rarely supported by empirical evidence. There is a risk, therefore, that the information needs of poultry producers regarding the costs associated with particular diseases are not being adequately met.

A systematic literature review of poultry production diseases was undertaken, first to scope the availability of studies that estimate the financial impacts of production diseases on poultry systems and second, based on these studies, estimates were generated of the magnitude of these impacts. Nine production diseases, selected by a panel of stakeholders as being economically important in the EU, were examined.

The review found that the poultry disease literature has primarily an epidemiological focus, with very few publications provideing estimates of the financial impacts of diseases. However, some publications quantified the physical impacts of production diseases and control interventions, e.g. using measures such as output volumes, mortality rates, bacteria counts, etc. Using these data in standard financial models, partial financial analyses were possible for some poultry production diseases.

Coccidiosis and clostridiosis were found to be the most common production diseases in broiler flocks, with salpingoperitonitis the most common in layers. While the financial impact of untreated diseases varied, most uncontrolled diseases were estimated to make flocks loss-making. However, in all cases, interventions were available that signficantly reduced these losses. The review reinforces the concern that the available academic 
literature is not providing sufficient information for poultry producers to decide on financially-optimal disease prevention and treatment measures.

Keywords: Poultry diseases; financial impacts; systematic literature review.

\section{Introduction}

There have been major changes in food consumption patterns in Western countries in the last 20 years, driven by increasing disposable incomes, changing food tastes and evolving health concerns (Traill, et al., 2014; European Commission, 2015). While egg consumption has remained fairly static (FAO, 2016a), there has been substantial growth in demand for poultry meat. Poultry meat is now the largest single source of meat-based protein in the diets of some countries, for example constituting $31 \%$ of all meat consumption in the UK and 43\% in the USA in 2011 (FAO, 2016b). The chicken meat sector has responded to this increased demand by intensification of broiler production systems, involving more vertical integration, increases in production scale, use of new technologies and higher rates of input use, including higher stocking rates (FAO, 2016c).

A negative side of increasing production intensity has been a rise in the prevalence of so-called 'production diseases' in poultry systems. These usually originate from a complex interaction of pathogens, animal genetics and environment, including deficiencies in housing, nutrition and management. Production diseases constitute various infections, but also physical conditions, such as ascites, caused by genetic developments designed to increase physical performance, and physical damage caused by objects, or chemical irritants, in the rearing environment. What these diseases have in common is that, while they may be endemic, even in the wild, they can become increasingly problematic with the intensity of the production system and failures in management (Liverani, et al, 2013). 
68 Production diseases compromise animal health and welfare and generate production

inefficiencies, which can reduce profitability, and increase both environmental footprint and levels of antibiotic use. Bennett (2012) has provided a conceptual understanding of the way in which production diseases impact the economics of poultry production systems, i.e. through:

1. Economic impacts internal to the farm:

- a loss of capital (i.e. animal mortality);

- reduction in the level of marketable outputs;

- reduction in (perceived or actual) output quality; and

- waste of, or higher level of use of, inputs.

2. Economic impacts both internal, and external, to the farm:

- resource costs associated with disease detection, diagnosis, prevention and control;

- negative animal welfare impacts (i.e. animal suffering) associated with disease;

- international trade restrictions due to disease and its control; and

- human health costs associated with diseases or disease control.

3. Economic impacts external to the farm such as effects on rural economies and tourism.

With producer margins being squeezed by increasing costs and limited opportunity to transmit extra costs to consumers due to lack of market power, plus fierce competition from international suppliers, the response of the poultry industry has been to drive down those production costs that can be controlled, including disease costs (Narrod et al., 2008). To allow the industry to prioritise the most financially beneficial disease prevention and control measures, robust empirical data are required on: the risks posed by various production diseases; the financial impacts of different diseases; and the efficacy of, and financial benefits from, different disease control measures. 
It might be be assumed that data to permit financially rational disease management decisions are available in the scientific literature. Much literature on poultry diseases exists, but data for individual diseases is seldom extensive and often lacking a financial dimension. Ubiquitous claims in research papers that particular poultry diseases lead to 'significant' financial impacts are seldom supported by empirical evidence. Consequently, data on the scale of financial losses associated with particular production diseases and the financial case for using control measures, are often lacking. Therefore, unless more informative industry data is available, there may be many poultry producers who are not implementing financially optimal disease prevention and treatment practices through lack of appropriate information. For example, in Denmark, vaccines are widely used to control salpingoperitonitis infections in layers without robust evidence of their efficacy (Christensen, 2016).

The study reported here undertook a systematic literature review to: determine the availability of data on the financial impacts of poulty production diseases; and a synthesis of this data to estimate the financial impacts of a number of production diseases and, where possible, the financial benefits of selected measures to control them. The study also had three sub-objectives. First, to show the relative risks presented by different production diseases, from data on their incidence. Second, to map the nature and distribution of disease costs, by showing where, in the production process, losses are occurring. Finally, to identify gaps in the literature on the financial impacts of poultry production diseases, to help guide future research.

\section{Method}

\subsection{The choice of production diseases}

To reduce the scope of the study, the most important production diseases were selected for analysis by a panel of 29 European animal scientists collaborating on the EU-funded PROHEALTH project. These came predominantly from veterinary medicine 
123 or animal science backgrounds. Nine production diseases were identified as the most

124 important by virtue of rates of incidence, revenue losses, or control problems, i.e.

125 respiratory diseases (Ascites; Infectious bronchitis), enteric (Coccidiosis; Clostridiosis),

126 locomotory (Tibial dischrondoplasia; Foot pad dermatitis; Keel bone damage),

127 reproductive (Salpingoperitonitis) and other disorders (Injurious feather pecking).

128

1292.2 The systematic literature review -

$130 \quad 2.2 .1$ Introduction

131 A systematic review was undertaken to identify studies reporting financial or

132 productivity impacts of these nine production diseases/conditions. As a first step, a

133 Web of Science search was undertaken using a tailored search term with keywords to

134 capture:

(i) economic (or financial) studies;

(ii) poultry as study subjects;

(iii) specific production diseases;

(iv) exclusion of topics appearing in searches but not relevant to the review;

(v) exclusions to remove studies based on non-intensive production systems; and

(vi) exclusions by text language, research domain, document type and publication prior to 1995 .

Abstracts found through the search were examined to exclude: duplications, those with no physical performance measures or financial data, or were based on modelling studies or reviews. This yielded 64 original studies. To supplement this list, additional publications were found by: reviewing the reference lists of publications already identified; a secondary web search using Google Scholar; website searches of organisations with an interest in poultry health, such as the FAO; and reference lists from recent poultry health research projects. This secondary search yielded a further 
15165 studies, making 129 in total. These publications encompassed peer-reviewed

152 journals and conference proceedings, as well as 'grey' literature. Few publicatons

153 assessed financial impacts, with most falling into the three categories shown in

154 Sections 2.2.2 through 2.2.4.

2.2.2 Surveys of disease invidence and severity

157 A few studies surveyed the incidence of production diseases. Incidence, which is the number of (new) disease incidents (or outbreaks) over a specified period of time, can be viewed as an indicator of risk. Incidence might be reported for a particular flock, or as an average across flocks (e.g. average annual incidence). In the studies reviewed, flocks were generally only deemed to have experienced a disease outbreak when symptoms met a given severity criterion i.e. they either exhibited clinical symptoms, or where subclinical disease resulted in fiancial impacts. As we were only interested in disease episodes that cause financial losses, the analysis of incidence here was limited to those surveys where this criterion was explicitly used.

2.2.3 Studies exploring the impact of uncontrolled diseases on production In this type of experimental study, birds could be deliberately exposed to a disease in either a controlled, or uncontrolled way. In the latter case, ambient levels of disease prevailed and therefore disease prevalence or severity was sometimes not elevated at all. Some of these studies employed a protected (or disease free) control group, while others did not.

2.2.4 Studies exploring the efficacy of measures to control production diseases Intervention studies were the most common type of study in the reviewed literature. These involved trials of wide-ranging scale, from a few dozen birds to tens of thousands of birds across many poultry businesses. These studies had a variety of formats, depending on the: 
- presence of a control group;

- presence of replicates;

- the number of interventions tested; and

- the level of control of environmental (rearing) conditions.

Studies with no control groups were excluded from the assessment. Where there were replicates of trials, averages over the replicates were calculated. When multiple, similar, interventions were used, for example several types of vaccine, an average over these interventions was taken. When multiple interventions were very different, for example contrasting a vaccine against a dietary nutrient, they were treated as separate interventions. When studies manipulated environmental conditions, in addition to target interventions, such as wetness of litter, then an average for the intervention over the multiple environmental conditions was estimated.

\subsection{The standard financial models}

Because financial data were rarely provided, the costs of diseases were estimated from data on changes to productive parameters (i.e. FCR, mortality and output volumes), using spreadsheet-based standard financial models for poultry enterprises. These were based on published data for market returns and production costs for EU 'average' conventional broiler and layer enterprises for 2013 (Appendix A).

\subsection{Weighting of data}

Recognizing that greater confidence can be placed on trials conducted on larger populations of birds, a weighting system was used in estimating averages across replicate trials. As studies often didn't state the exact number of birds in a trial, the value of the weights increases with size ranges using a geometric progression with a common ratio of two. By this means, data from experiments with up to 1,000 birds were 
205 given a weight of one, 1,001-10,000 birds had a weight of two, 10,001-25,000 birds a

206 weight of four, and more than 25,000 birds a weight of eight.

207

208

3. Results

2093.1 The number of relevant studies identified from the systematic literature review

210 Table 1 lists the number of relevant studies identified for the nine study production

211 diseases, classified by the type of intervention used. Studies reporting no interventions

212 in Table 1 either examined the impacts of the uncontrolled disease, or were surveys of

213 disease incidence.

214

215 Table 1. The number of publications found reporting the impacts of poultry production

216 diseases and/or impacts of interventions to control them.

\begin{tabular}{|c|c|c|c|c|c|c|}
\hline \multirow{3}{*}{ Respiratory diseases } & \multicolumn{5}{|c|}{ Type of prevention/control intervention } & \multirow[b]{2}{*}{$\begin{array}{c}\text { Total } \\
\text { studies }^{2}\end{array}$} \\
\hline & \multirow[t]{2}{*}{ None } & \multirow[t]{2}{*}{$\begin{array}{c}\text { Anti- } \\
\text { microbials }\end{array}$} & \multirow[t]{2}{*}{ Vaccination } & \multirow[t]{2}{*}{ Housing } & \multirow[t]{2}{*}{ Other $^{3}$} & \\
\hline & & & & & & \\
\hline $\begin{array}{l}\text { Pulmonary hypertension syndrome } \\
\text { (ascites) }\end{array}$ & 1 & - & - & . & 9 & 10 \\
\hline Infectious bronchitis (IB) & 14 & - & 5 & 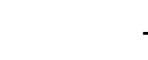 & . & 19 \\
\hline \multicolumn{7}{|l|}{ Enteric diseases } \\
\hline Coccidiosis & 1 & 7 & 8 & . & . & 16 \\
\hline $\begin{array}{l}\text { Clostridiosis (C. perfringens, } C \text {. } \\
\text { septicum) }\end{array}$ & 1 & 10 & 3 & - & 1 & 15 \\
\hline \multicolumn{7}{|l|}{ Locomotory diseases } \\
\hline Tibial dischrondoplasia & 3 & - & - & 4 & 7 & 14 \\
\hline Foot pad dermatitis & 3 & - & - & - & 12 & 15 \\
\hline Keel bone damage & 10 & - & - & 3 & 5 & 18 \\
\hline \multicolumn{7}{|l|}{ Reproductive disorder } \\
\hline $\begin{array}{l}\text { Salpingoperitonitis syndrome, } \\
\text { (colibacillosis) }\end{array}$ & 9 & 1 & - & - & 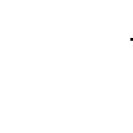 & 10 \\
\hline
\end{tabular}

Other disorders 


\begin{tabular}{lcccccr} 
Injurious feather pecking & 7 & - & - & 4 & 1 & 12 \\
\hline Total & 45 & 18 & 16 & 11 & 35 & 129
\end{tabular}

217

218

219

220

221

222

223

224

225

226

227

228

229

230

231

232 233

${ }^{1}$ For either prophylactic or curative treatment.

${ }^{2}$ Some studies had multiple interventions, so the total number of studies may not equal the number of interventions.

3 'Other' usually involves changing parameters in the rearing environment, such as temperature, or humidity.

\subsection{Disease incidence}

This data came from studies ranging from large-scale surveys to small-scale laboratory trials. Because of the dominance of small-scale studies in the literature, the estimates in Table 2 should be treated with caution. Coccidiosis and clostridiosis would seem to be present in $90-100 \%$ of poultry flocks (Williams, 1998; Miller et al., 2010). There is a far greater incidence of the subclinical forms of these diseases, but these are only included in the incidence estimates where they cause productivity losses. The lowest reported disease incidence (at 5\%) was reported for ascites, but most production diseases appear to have a reported incidence of over $30 \%$ of flocks.

Table 2. The incidence of production diseases and sources of this data

\begin{tabular}{|c|c|c|c|}
\hline & & $\begin{array}{l}\text { Incidence } \\
\% \text { of flocks) }\end{array}$ & Sources of data \\
\hline Ascites & \multirow{5}{*}{$\begin{array}{l}\frac{0}{0} \\
\frac{0}{4} \\
\frac{\overline{0}}{\bar{L}} \\
\frac{\overline{0}}{\overline{0}}\end{array}$} & 5 & $\begin{array}{l}\text { Hassanzadeh et al. (2005); Hassanzadeh et al. (2008); } \\
\text { Maxwell and Robertson (1998) }\end{array}$ \\
\hline Coccidiosis & & $90-100$ & Williams $(1998,1999)^{1}$ \\
\hline Clostridiosis & & $90-100$ & Miller et al. $(2010)^{1}$ \\
\hline $\begin{array}{l}\text { Footpad } \\
\text { dermatitis }\end{array}$ & & 41.1 & $\begin{array}{l}\text { Allain et al. (2009); de Jong et al. (2014); Pagazaurtundua } \\
\text { and Warriss (2006) }\end{array}$ \\
\hline $\begin{array}{l}\text { Tibial } \\
\text { dyschondroplasia }\end{array}$ & & 35.6 & $\begin{array}{l}\text { Edwards (1990); Edwards and Sorensen (1987); Leeson et } \\
\text { al. (1995); Lilburn and Lauterio (1989); Lui et al. (1992); } \\
\text { Petek et al. (2005); Trablante et al. (2003); Yalcin et al. } \\
\text { (2007) }\end{array}$ \\
\hline Salpingoperitonitis & \lrcorner & त 49.5 & Fossum et al. $(2009)^{2}$ \\
\hline
\end{tabular}




\begin{tabular}{lll}
\hline $\begin{array}{l}\text { Injurious feather } \\
\text { pecking }\end{array}$ & 35 & Lambton et al. (2013) \\
\hline
\end{tabular}

235

236

237

238

239

240

241

242

243

244

245

246

247

248

249

250

251

252

253

254

255

256

257 Table 3. Impact of severe uncontrolled production disease on flock mortality rates

$\begin{array}{cc}\text { Mortality } & \text { Sources of data } \\ \text { change (\%) } \\ \text { (range \%) }\end{array}$

${ }^{1}$ Exact estimates of incidence for coccidiosis and clostridiosis are unavailable but sources indicate these infections are close to ubiquitous.

${ }^{2}$ Estimate of incidence of coliobaccilosis i.e. e-coli infections.

\subsection{Mortality rates}

Financial impacts resulting from elevated bird mortality comes from: loss of sales; expenditure on housing, feed and health care for birds that subsequently die; and the cost of disposal of carcasses. Once a disease is present in a flock, mortality rate is determined both by the severity of the disease challenge, and other factors such as the type of bird, breed, age at end of productive life-cycle and housing and production system, e.g. free-range. In an average commercial setting, with 'standard' disease management practice, cumulative mortality in layers, from all causes, ranges from 6 $11 \%$, with an average of 7.7\% (van Horne, 2014; Weber et al., 2003; Merle et al., undated; Vitse et al., 2005; and Bell, 2012). Cumulative mortality in broilers is somewhat lower, ranging between $4-6 \%$ with an average of $4.7 \%$ (Havenstein et al., 2003; ACP, 2006; Gocsik et al., 2014; and van Horne and Bont, 2014). Table 3 shows the change in rate of mortality resulting from uncontrolled production diseases that are classified in studies as severe, i.e. where they have measureable financial impact. Also shown are the ranage of mortality values (in parentheses) found in the literature, where more than one usable estimate is available.

\section{Broilers}




\begin{tabular}{|c|c|c|}
\hline $\begin{array}{r}\text { Tibial } \\
\text { dischondroplasia }\end{array}$ & +1 & Morris (1993) \\
\hline Acites & $\begin{array}{c}+36.3 \\
(15.2-68)\end{array}$ & $\begin{array}{l}\text { Acar et al. (1995); Arce-Menocal et al. (2009); Camacho- } \\
\text { Fernandez et al. (2002); Izadinia et al. (2010) }\end{array}$ \\
\hline Clostridiosis & $\begin{array}{c}+336 \\
(45.4-1500)\end{array}$ & $\begin{array}{l}\text { Lovland and Kaldhusdal (2001); Miller et al. (2010); Tactacan et al. } \\
\text { (2013); Zhang et al. (2010) }\end{array}$ \\
\hline $\begin{array}{r}\text { Footpad } \\
\text { dermatitis }\end{array}$ & $\begin{array}{c}+12.7 \\
(-1-87.5)\end{array}$ & $\begin{array}{l}\text { Bilgili et al. (2009); Cengiz et al. (2011); de Jong et al. (2014); } \\
\text { Ekstrand et al. (1997); Martland (1985); Mayne et al. (2007); Taira } \\
\text { et al. (2013); Wang et al. (2010) }\end{array}$ \\
\hline
\end{tabular}

\section{Laying flocks}

Keel bone $\quad+71.5 \quad$ Nasr et al. (2013); Petrik et al. (2015); damage $\quad(65.1-77.8)$

Salpingoperitonitis $\quad+57 \quad$ Jordan et al. (2005); Medina (2008), Thøfner et al. (2015)

Note: Change in mortality is the change to the base, or 'normal', mortality rate resulting from uncontrolled disease.

Note: Coccidiosis, Salpingoperitonitis and Injurious pecking are omited from the table due to lack of data.

Mortality impacts vary considerably between, and within, production diseases, and disease-driven mortality rates much higher than those in Table 3 have been observed in commercial practice. However, the headline observation is the paucity of studies on the mortality impacts of specific diseases in the literature. This problem is compounded by methodological weakness that affect the available data, i.e. some studies either have no experimental control, or they have a disease-challenged control, rather than a true (disease free) control. The lack of robustness in the available data is exemplified by the mortality impacts estimated for keel bone damage, which are considerably

271 higher in the studies cited than have been observed by the authors in commercial 272 farming practice.

$274 \quad 3.4 \quad$ Loss of physical outputs

275 Production diseases can lead to financial losses through reductions in the physical output from flocks (see Table 4). In broilers this can take the form of reduced terminal 
277

278

279

280

281

282

283

284

285

286

287

288

289

290

weight (or rather, a longer growing period to reach the desired weight, requiring more feeding and less efficient utilization of resources). In layers this would mean reduced egg numbers, but also impairment of output quality. Loss of quality in broilers means broken bones, damaged or discoloured muscle, or skin burns, leading to carcass downgrades, or trimmings. In layers, this is experienced as smaller or mishapen eggs, thin shells and colour change, resulting in downgrades or rejections.

Reviewed studies report reductions in terminal body weight in broilers range from zero for ascites (although Swayne, 2013, suggests some weight loss is possible), to a high of $17.7 \%$ for coccidiosis. There is a relatively high reported loss of body weight from tibial dyschondroplasia. This effect is likely due to the fact that the condition can cause considerable pain, and birds in pain move less and consume less food.

Table 4. Impact of severe and uncontrolled production disease on physical outputs

\begin{tabular}{|c|c|c|c|}
\hline Broilers & $\begin{array}{c}\text { Live- } \\
\text { weight (\% } \\
\text { change) } \\
\text { (range) }\end{array}$ & $\begin{array}{l}\text { Carcass downgrades } \\
\text { (\% change) } \\
\text { (range) }\end{array}$ & Sources of data \\
\hline $\begin{array}{r}\text { Tibial } \\
\text { dischondroplasia }\end{array}$ & -10 & $<1$ & $\begin{array}{l}\text { Burton et al. (1981); Edwards and } \\
\text { Sorensen (1987); Morris (1993) }\end{array}$ \\
\hline Acites & 0 & N.A. & $\begin{array}{l}\text { Acar et al. (1995); Arce et al. (1992); } \\
\text { Arce-Menocal et al. (2009); Camacho- } \\
\text { Fernandez et al. (2002); Izadinia et al. } \\
\text { (2010); Kalmar et al. (2013); Khajali et } \\
\text { al. (2007); Maxwell and Morris (1992); } \\
\text { Rincon (2000); Robertson (1998) }\end{array}$ \\
\hline Clostridiosis & -1.24 & N.A. & Lovland and Kaldhusdal (2001) \\
\hline Coccidiosis & $\begin{array}{l}-17.7 \\
(-17.3--18.1)\end{array}$ & N.A. & $\begin{array}{l}\text { Abdelrahman et al. (2014); Li et al. } \\
\text { (2005) }\end{array}$ \\
\hline $\begin{array}{r}\text { Footpad } \\
\text { dermatitis }\end{array}$ & $\begin{array}{l}-7.3 \\
(0.8--14.6)\end{array}$ & $<1$ & $\begin{array}{l}\text { Cengiz et al. (2011); de Jong et al. } \\
\text { (2014); Martland (1985) }\end{array}$ \\
\hline Laying Flocks & $\begin{array}{l}\text { Egg } \\
\text { numbers }\end{array}$ & $\begin{array}{l}\text { Egg } \\
\text { quality }\end{array}$ & \\
\hline
\end{tabular}




\begin{tabular}{|c|c|c|c|c|}
\hline $\begin{array}{r}\text { Keel bone } \\
\text { damage }\end{array}$ & $\begin{array}{l}-3.5 \\
(-1.2--5.7)\end{array}$ & -3.2 & & Nasr et al. (2012); Nasr et al (2013) \\
\hline $\begin{array}{l}\text { Infectious } \\
\text { bronchitis }\end{array}$ & $\begin{array}{l}-32.9 \\
(-3--50)\end{array}$ & $\begin{array}{l}-8.7 \\
(-7.3--11.36)\end{array}$ & N.A. & $\begin{array}{l}\text { Bisgaard M. (1976); Muneer et al. } \\
\text { (1986); Muneer et al. (1987); Ignjatovic } \\
\text { and Sapats (2000); Muneer et al. } \\
(2000)\end{array}$ \\
\hline Salpingoperitonitis & N.A. & N.A. & $<1$ & Bisgaard and Dam (1981) \\
\hline $\begin{array}{r}\text { Injurious feather } \\
\text { pecking }\end{array}$ & $\begin{array}{l}-5.1 \\
(-2.6--7.5)\end{array}$ & 0 & 0 & $\begin{array}{l}\text { Glatz (2001); Hagger et al. (1989); } \\
\text { Peguri and Coon (1993); Leeson and } \\
\text { Morrison (1978) }\end{array}$ \\
\hline
\end{tabular}

291

292

293

294

295

296

297

298

299

300

301

302

303

304

305

306

307

308

309

310

311

Note: N.A. means that suitable data are not available.

Disease impacts on laying flocks (number of eggs) rangese between $3.5 \%$ and $32.9 \%$, although greater losses may be observed in commercial practice. The impact of keel bone damage and injurious pecking on egg production should be low, unless birds contract secondary infections. In the case of feather pecking, feather loss means elevated loss of body heat, so that birds must eat more food to regulate body temperature and continue normal egg laying. While the impacts of infectious bronchitis can be severe, these effects last for only a small part of the productive life of a hen, typically 1-8 weeks. If a disease does not kill a hen, it will recover, and so, typically, will the laying percentage, although productivity may not always recover to pre-disease levels (Ignjatovic and Sapats, 2000; and Bisgaard, 1976). Based on available data, infectious bronchitis has the most significant impact on egg downgrades.

\subsection{Impaired feed conversion ratio}

All production diseases, if severe enough, impair birds' FCR i.e. they lower feed conversion efficiency. Where the bird cannot compensate by eating more, this can lead to loss of physical output. Where additional food is available and the bird has the capacity to consume it, physical outputs need not be reduced, but financial losses will still be experienced due to elevated feed consumption. Reductions in FCR ranged from zero for ascites to reductions of $25.9 \%$ for severe feather pecking (Table 5). 
313 Table 5. Impact of severe, uncontrolled, production disease on the feed conversion

314 ratio (FCR)

\begin{tabular}{|c|c|c|}
\hline & $\begin{array}{l}\text { Reduction in } \\
\text { FCR (\%) } \\
\text { (range) }\end{array}$ & Sources of data \\
\hline \multicolumn{3}{|l|}{ Broilers } \\
\hline Acites & 0 & $\begin{array}{l}\text { Acar et al. (1995); Arce et al. (1992); Arce-Menocal et al. (2009); } \\
\text { Camacho-Fernandez et al. (2002); Izadinia et al. (2010); Kalmar et al. } \\
\text { (2013); Khajali et al. (2007); Maxwell and Robertson (1998); Morris } \\
\text { (1992); Rincon, (2000) }\end{array}$ \\
\hline Clostridiosis & $\begin{array}{l}16.4 \\
(-3.7-70.5)\end{array}$ & $\begin{array}{l}\text { Lovland and Kaldhusdal (2001); Miller et al. (2010); Tactacan et al. } \\
\text { (2013); Zhang et al. (2010) }\end{array}$ \\
\hline Coccidiosis & 17.7 & Abdelrahman et al. (2014); Li et al. (2005) \\
\hline $\begin{array}{r}\text { Footpad } \\
\text { dermatitis }\end{array}$ & $\begin{array}{l}3.3 \\
(1.06-4.35)\end{array}$ & Cengiz et al. (2011); de Jong et al. (2014) \\
\hline
\end{tabular}

\section{Laying flocks}

Injurious feather 25.9

Glatz (2001); Leeson and Morrison (1978); Peguri \& Coon (1993)

pecking $(-5.1--49.7)$

315 Note: Suitable data are not available for Tibial Dischondroplasia, Keel bone damage, Infectious bronchitis

316 and salpingoperitonitis.

3.6 Financial impacts of uncontrolled production diseases

320 The financial impacts of these diseases were estimated by applying percentage

321 changes in physical outputs to the standard broiler and layer financial models

322 (Appendix A). On the few occasions where data were available from the studies on

323 changes to input costs resulting from the diseases, or interventions, these were also

324 used in the financial models. For six of the diseases there were sufficient data to

325 undertake financial analyses, while for three there were not. In Figures 1 and 2, the

326 darker shaded bars represent the financial losses per bird, averaged over the flock,

327 arising from the uncontrolled diseases and the lighter bars show the losses that would

328 be incurred after applying the best available interventions to control them. Not 
surprisingly, average losses for layers are higher than broilers because layers have a longer productive life (around 56 weeks (RSPCA, 2016) and thus generate more revenue. Broilers are usually slaughtered around 6-7 weeks in the EU and USA (EFSA, 2010; National Chicken Council, 2016), depending on growth rates and desired slaughter weights.

Uncontrolled clostridiosis caused the greatest reported losses, at around $€ 0.32$ per bird averaged over the flock, while losses from uncontrolled coccidiosis amounted to $€ 0.21$ per bird. Based on the financial model used here, confirmed by anecdotal industry evidence, the net (profit) margin for a typical commercial broiler enterprise in the EU in 2013 was low, at around 10 Euro Cents per bird. With margins as tight as this, all of the production diseases costed here would, when unconstrained, make affected flocks loss-making.

Based on the standard financial model, laying hens typically generated a margin of around $€ 6$ per bird in 2013. Figure 2 shows that, among the studied diseases, keel bone damage causes the largest financial losses in laying hens, at around €3.5 per bird averaged over the flock. However, this result should be treated with some caution in view of the doubts raised above over the scale of mortality losses reported for this disease.

A number of possible disease costs have not been accounted for, due to lack of data. Typically, there are no data available from most disease impactstudies on labour, vet and medicine costs, additional carcass disposal costs, or costs associated with the disruption of normal husbandry practices resulting from diseases, such as delays to thinning and depopulation to allow extra time for broilers to reach target weight. Also not reported are losses from increased heterogeneity of broiler weights in a cohort, meaning that a greater proportion of birds would fail to meet buyer requirements for 
357

358

359

360

361

362

363

364

365

367

368

369

370

371

372

373

permissible weight range and would have to be sold at lower prices, often through alternative marketing channels.

Figure 1. Financial losses due to four production diseases (controlled and uncontrolled) in broiler flocks.

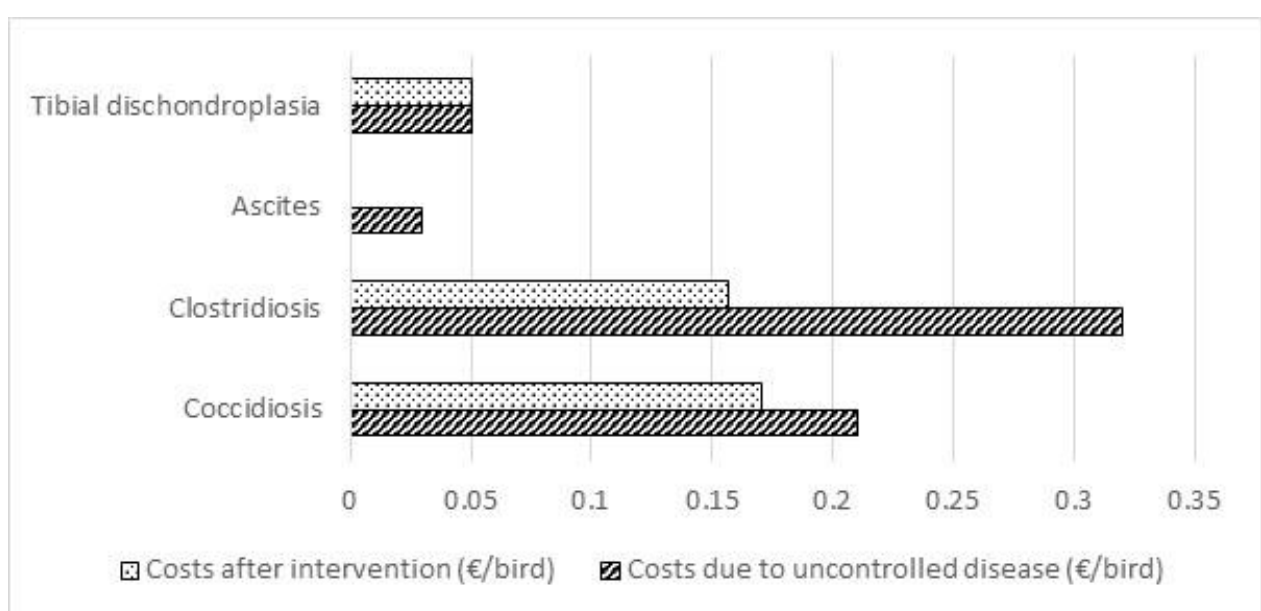

Figure 2. Financial losses due to two production diseases (controlled and uncontrolled) in laying flocks.

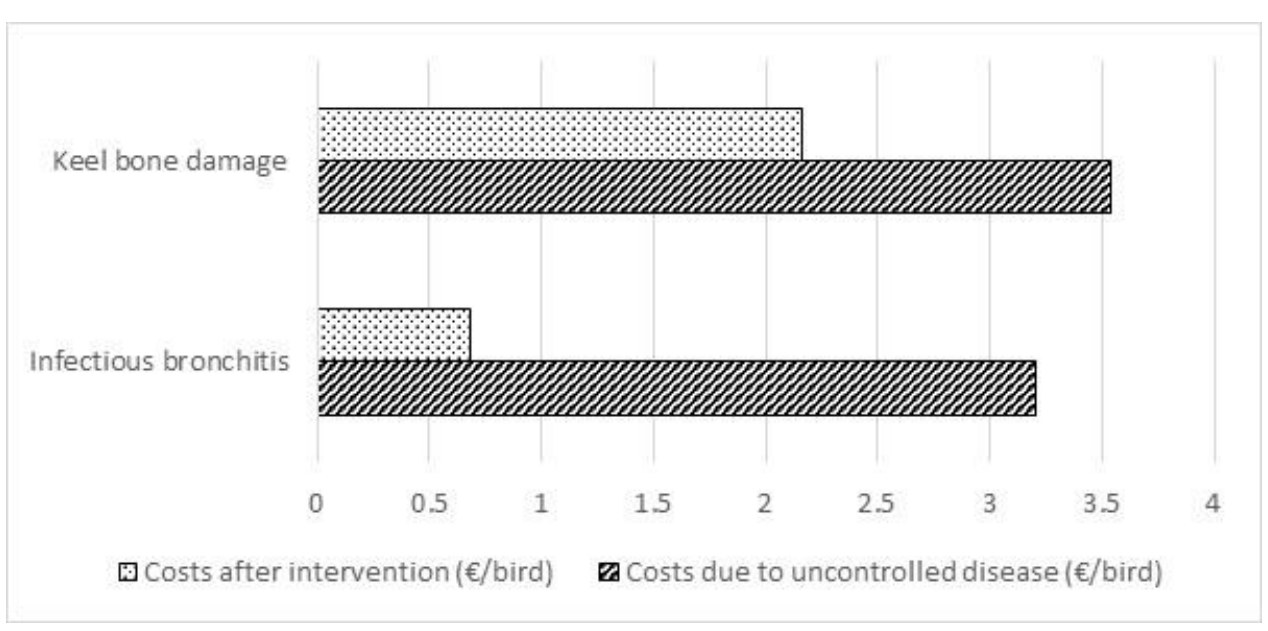

3.7 The efficacy of interventions

Interventions to control production diseases in poultry are of two types, both adding to production costs: treatment and prevention measures. Once a disease outbreak has occurred, producers react with one or more courses of treatments, often with veterinary support. Because many diseases are endemic, and difficult or expensive to control 
once established, producers sometimes deploy preventive measures to try to reduce the risk of outbreaks and/or their severity. The cost of therapeutic treatments can be reduced if treatment begins early in a disease outbreak and so, producers may also increase expenditure on health monitoring to identify early signs of disease.

As Table 6 shows, many types of intervention have been evaluated in the literature, although there are few studies for any particular intervention. There is some heterogeneity within type of intervention studied for each disease. For example, in the anti-microbial category, treatments might be dietary supplements, probiotics, bacteriophage therapy, or antibiotics, with variation within these categories based on compounds or brands used, and concentrations of active ingredients. The data presented in Figures 1 and 2 represent the single most efficacious intervention reported in the literature for each disease. These estimates provide a sense of the higher end of the achievable levels of control that might be expected in a commercial setting.

Figures 1 and 2 show that there are considerable differences between these diseases in terms of both the financial losses caused when uncontrolled, and the extent to which interventions can reduce these losses. Tibial dyschondroplasia, for example, causes relatively small financial losses, but these are relatively difficult to eliminate. Conversely, diseases such as clostridiosis and infectious bronchitis, while resulting in very high financial costs when uncontrolled, can be reduced effectively through interventions. The diseases that would seem most problematic are those, such as keel bone damage, which lead to high financial costs when unconstrained and which resist attempts to control them. Based on this analysis, coccidiosis appears to fall into this class, with lower efficacy of interventions than for other diseases. However, producers report that both vaccines and anti-microbials offer significant means of disease control in a commercial setting. 
403 Table 6. Types of intervention to control production diseases from the literature review.

\begin{tabular}{|c|c|c|}
\hline & $\begin{array}{l}\text { Class of } \\
\text { measure }\end{array}$ & Types of intervention and data sources \\
\hline \multicolumn{3}{|l|}{ Broilers } \\
\hline Tibial & Prevention & Manipulation of nutrients (Edwards, 1990) \\
\hline \multirow[t]{3}{*}{ dischondroplasia } & & Manipulation of feed consumption (Edwards and Sorensen, 1987; \\
\hline & & Onbasilar et al., 2007) \\
\hline & & Manipulation of egg incubation temp. (Yalcin et al., 2007) \\
\hline \multirow[t]{3}{*}{ Acites } & Prevention & Feed restriction - full rearing period (Arce et al. 1992; Camacho- \\
\hline & & Fernandez et al., 2002; Rincon 2000) \\
\hline & & $\begin{array}{l}\text { Feed restriction - early weeks (Acar et al., 1995; Arce et al., 1992; } \\
\text { Khaiali et al. 2007) }\end{array}$ \\
\hline \multirow{3}{*}{ Clostridiosis } & Treatment & $\begin{array}{l}\text { Khajall et al., 2007) } \\
\text { Antibiotics (Tactacan et al., 2013; Zhang et al., 2010) }\end{array}$ \\
\hline & & Bacteriophage therapy (Miller et al., 2010) \\
\hline & & Other antimicrobials (Tactacan et al., 2013) \\
\hline \multirow[t]{5}{*}{ Coccidiosis } & Prevention & $\begin{array}{l}\text { Vaccines (Lee et al., 2009; Li et al., 2005; Miguel et al., 2008; Shirley et } \\
\text { al., 1995; Sou et al., 2006; Vermeulen et al., 2001; Williams et al., 1999; } \\
\text { Williams and Gobbi, 2002) }\end{array}$ \\
\hline & & Probiotics (Abdelrahman et al., 2014) \\
\hline & & Herbal treatments (Miguel et al., 2008) \\
\hline & & Anticoccidials (Abdelrahman et al., 2014; Lee et al., 2009; Li et al., 2005; \\
\hline & & $\begin{array}{l}\text { Miguel et al., 2008; Sou et al., 2006; Williams et al., 1999; Williams and } \\
\text { Gobbi, 2002) }\end{array}$ \\
\hline \multirow[t]{2}{*}{$\begin{array}{l}\text { Footpad } \\
\text { dermatitis }\end{array}$} & Prevention & $\begin{array}{l}\text { Manipulation of litter moisture (Cengiz et al., 2011; de Jong et al., 2014; } \\
\text { Ekstrand et al., 1997; Martland, 1985; Mayne et al., 2007; Taira et al., } \\
\text { 2013; Wang et al., 2010) }\end{array}$ \\
\hline & & Variation of litter materials (Bilgili et al., 2009) \\
\hline \multicolumn{3}{|l|}{ Laying flocks } \\
\hline $\begin{array}{r}\text { Keel bone } \\
\text { damage }\end{array}$ & Prevention & $\begin{array}{l}\text { Switch from unenriched to enriched cages (Petrik et al., 2015; Sherwin } \\
\text { et al., 2010; Wilkins et al., 2011) }\end{array}$ \\
\hline $\begin{array}{l}\text { Infectious } \\
\text { bronchitis }\end{array}$ & Prevention & $\begin{array}{l}\text { Vaccines (Cook et al., 1999; Faramarzi et al., 2014; Jones et al., 2005; } \\
\text { Tarpey et al., 2006; Tawfik et al., 2013) }\end{array}$ \\
\hline \multirow[t]{4}{*}{ Salpingoperitonitis } & Prevention & Probiotics (Shini et al., 2013) \\
\hline & & Inoculation (Reid and Bocking, 2003) \\
\hline & & Vaccination (Gregersen, et al., 2010) \\
\hline & Treatment & $\begin{array}{l}\text { Antimicrobials (Balevi et al., 2001; Nahashon et al., 1996; Willis and } \\
\text { Read, 2008) }\end{array}$ \\
\hline \multirow{5}{*}{$\begin{array}{r}\text { Injurious feather } \\
\text { pecking }\end{array}$} & Prevention & Housing (Fossum et al., 2009) \\
\hline & & Beak trimming (Craig and Lee,1990) \\
\hline & & Enriched environment (El-Lethey et al., 2000; Lambton et al., 2013) \\
\hline & & Reduced stocking rates (Nicol et al., 1999) \\
\hline & & Feed modification (Ambrosen and Petersen,1997) \\
\hline
\end{tabular}

406 There are two possible explanations for the discrepancy between the results of the

407 scientific trials and real-world experience. First, that the few studies available are

408 simply generating unrepresentative results and, second, and perhaps more likely, that

409 the reviewed studies are capturing sub-clinical disease impacts. Observation of 
410 commercial practice suggests that coccidiostats, such as ionophore antibiotics, while

411 effective at controlling clinical disease, are seemingly less effective at controlling

412 subclinical impacts, leading to losses through reduced feed intake and feed conversion

413 efficiency (Christensen, 2016).

\section{Discussion}

416 Our study found that there is an almost complete absence of published studies

417 generating data on the financial impacts of these nine poultry production diseases.

418 Generalising from this, it might be supposed that the entire poultry disease literature

419 has very much an epidemiological, rather than financial, focus.

To estimate the financial impacts of the nine poultry production diseases, and control interventions, it was necessary to apply data on changes to productive parameters to standard financial models (for broilers and layers) in order to monetise them. However, there are significant gaps, even in the data on the impacts of diseases on productive parameters, a case in point being salpingoperitonitis, where there are insufficient data to permit any estimation of financial impact. This is perhaps explicable in view of the tendency for salpingoperitonitis to occur in conjunction with other E. Coli-induced conditions, such as airsaculitis, and secondary infections such as septicemia.

There is great heterogeneity of research objectives and methodology in the reviewed studies, with some focusing on disease incidence, others on disease severity, others seeking to capture the physical impacts of the disease itself, while others are concerned only with the efficacy of control interventions. As a consequence of this, together with the few studies, there is little or no replication in the literature and, sometimes, essential data are only available from a single study. This limitation affects

436 the level of confidence that can be placed in the available data when generalising to 437 the whole sector. 
439 The lack of focus on finanial impacts in studies means that, even if data on changes to

440 productive parameters are available and can be monetised, impacts on some cost categories, such as vet and medicine costs, still cannot be captured. With very little data on the impact of production diseases on the quality of outputs, the full financial impact of downgrades to carcasses or eggs cannot be accounted for, and so disease impacts may be underestimated. The lack of data on the cost of interventions means that the estimates of the financial savings resulting from using them may be overestimated in our study.

Different studies often show a wide range of severity of impacts for the same disease.

More extreme impacts than estimated here might occur in commercial practice for a number of reasons, including variations in: rearing environment; breed; management quality; and the pathogenicity of infections. An additional cause of variation is the occurrence of secondary infections. Most studies do not report data where secondary infections are known to have occurred, on the grounds that such data would bias impact estimates for the individual production diseases themselves. However, it must be acknowledged that part of the set of negative consequences arising from the occurrence of production diseases is an elevated risk of secondary infections from other diseases.

For the reasons identified above, it is concluded that there are deficiencies in the

459 literature (and in the underlying reported research) resulting in data which are difficult

460 to use. Thus, the financial impacts estimated for the production diseases examined here should be treated with some caution. Despite this, the claims made by many authors in the poultry disease literature that production diseases can have significant financial impacts would appear correct, even though these authors seldom supply any empirical financial evidence supporting these claims. 
466 While poultry farms with elevated levels of production diseases can make substantially

467 less profit than farms with low disease levels, these losses can be significantly reduced by a range of prevention measures, such as vaccinations, or improved litter management, nutrition and hygiene, as well as curative treatments. The financial benefits of interventions to control production diseases vary greatly according to disease and the intervention chosen. The losses associated with diseases such as

472 clostridiosis, for example, can be significantly reduced through use of antimicrobials, but others, such as keel bone damage, present a greater challenge.

475 The reliance of the poultry industry on the use of antimicrobials to control infectious 476 diseases highlights the risks to the financial sustainability of the sector from the 477 continuing growth in farm bacterial reservoirs with resistance to antimicrobial treatments (Aminov and Mackie, 2007; Sykes, 2010, EFSA and ECDPC, 2016).

These risks occur on three fronts. First, some antibiotics commonly used for the treatment of diseases may lose their efficacy. Second, government action plans, such as the EU Action Plan Against the Rising Threats from Antimicrobial Resistance (EU, 2011), which are designed to drive more responsible use of antibiotics, may make some antibiotics less readily available. Third, although there have been few official bans on the use of selected antibiotics so far, such as the US ban on Fluoroquinolones (FDA, 2005), governments may adopt the 'precautionary principle', and issue complete bans on the use of some antibiotics.

\section{Conclusions}

490 In light of this growing threat, there is a pressing need for the poultry research 491 community to help identify cost-effective alternatives to antibiotics which offer similar levels of disease control. These could include: novel substances to strengthen the 
517 In order to meet the future informational needs of the poultry industry, the focus of

poultry immune response to bacterial infection; naturally occurring bacteriophages; novel vaccinations; and enhanced biosecurity measures on farm. Although some rigorous individual studies of alternative approaches have been undertaken, there is insufficient data across the literature to evaluate them. Failure to develop these alternatives could significantly, and negatively, impact the future financial sustainability of the global poultry industry.

There are strong hints in the literature that some interventions, particularly in relation to biosecurity measures, reduce disease incidence, prevalence and severity, for multiple production diseases simultaneously. The use of single interventions to control multiple diseases would be very advantageous for an industry faced with small profit margins, volatile markets, and the possibility of further regulation. The industry would, therefore, benefit from a more holistic effort from the research community to identify the most useful and cost-effective multi-functional interventions to reduce disease-related financial losses.

The analysis above has revealed a disconnect between the requirements of the poultry industry for data on the financial impacts of diseases and control measures and the goals of researchers in the non-commercial poultry disease research community. As a consequence, the value of such research, even if it targets relevant production diseases and interventions, is of less value than it could be. In view of this, the question might reasonably be asked, where are commercial producers and their advisors getting the data on which to plan their disease management programmes?

$$
\text { academic poultry disease research needs to be changed. Studies need to generate }
$$
data not only on the first-order physical impacts of production diseases, but also secondary and financial impacts, as is currently already being achieved commonly in 
521 research on pig and dairy cow diseases. This means collecting data from abbatoirs on

522 the impact of diseases on product quality, as well as data from farm trials and lab-

523 based experiments on changes to the levels of input use resulting from diseases and

524 the interventions to control them. This would require a more inter-disciplinary approach

525 to research, involving not just veterinarians or animal scientists, but also agricultural

526 economists.

527

528

\section{Acknowledgement}

529 The work on which this paper is based was made possible by funding from the EU's

530 DG Research Framework 7 Programme PROHEALTH project http://www.fp7-

531 prohealth.eu/

\section{Conflict of interest}

The authors know of no conflict of interest in relation to the production or publication of 534 this article.

\section{References}

537 Abdelrahman, W., Mohnl, M., Teichmann, K., Doupovec, B., Schatzmayr, G.,

538 Lumpkins, B., Mathis, G., 2014. Comparative evaluation of probiotic and salinomycin

539 effects on performance and coccidiosis control in broiler chickens. Poultry Sci. 93, $540 \quad 3002-3008$.

541

542 Acar, N., Sizemore, F.G., Leach, G.R., Wideman, R.F., Owen, R.L., Barbatio,

543 G.F.,1995. Growth of broiler chickens in response to feed restriction regimens to

544 reduce ascites. Poultry Sci. 74, 833-843.

546 Agro Business Consultants Ltd., 2012. ABC Budgeting \& Costings Book, 83rd ed.

547 November 2016. Melton Mowbray, UK. 
549 Allain, V., Mirabito, L., Arnould, C., Colas, M., Le Bouquin, S., Lupo, C., Michel, V.,

550 2009. Skin lesions in broiler chickens measured at the slaughterhouse: relationships

551 between lesions and between their prevalence and rearing factors. Brit. Poultry Sci. 50, $552 \quad 407-417$.

553

554 Ambrosen, T., Petersen, V.E., 1997. The influence of protein level in the diet on

555 cannibalism and quality of plumage of layers. Poultry Sci, 76, 559-563.

556

557 Aminov, R.I., Mackie, R.I., 2007. Evolution and ecology of antibiotic resistance genes.

558 FEMS Microbiol. Lett. 271, 147-61.

559

560 Arce, J., Berger, M., Lopez Coello, C., 1992. Control of ascites syndrome by feed

restriction techniques. J. Appl. Poultry Res. 1, 1-5.

562

Arce-Menocal, J. Avila-Gonzalez, E., lopez-Cello, C., Garibay-Torres, G., Martinez-

Lemus, L.A. 2009. Body weight, feed-particle size and ascites incidence revisited. J.

Appl. Poultry Res. 18, 465-471.

566

567

Assured chicken production (ACP) standards, 2006. Key health and welfare indicators for broiler production. http://www.journals.cambridge.org/ (accessed May 2016)

Balevi, T., Ucan, U.S., Coskun, B., Kurtoglu, V., Cetingul, I.S., 2001. Effect of dietary probiotic on performance and humoral immune response in layer hens. Brit. Poultry Sci. 42, 456-461.

574 Bell, D., 2012. U.S. experiences with Lohmann Selected Leghorn (LSL-Lite) layers, 575 Part 3: Livability. Lohmann Information, 47, 22-33. 
577 Bennett, R. (2012) Economic rationale for interventions to control livestock disease.

578 Eurochoices, $11(2), 5-10$.

579 Bilgili, S.F., Hess, J.B., Blake, J.P., Macklin, K.S., Saenmahayak, B., Sibley, J.L., 2009.

580 Influence of bedding material on footpad dermatitis in broiler chickens. J. Appl. Poultry

581 Res. 18, 583-589.

582

583 Bisgaard, M., 1976. The influence of infectious bronchitis virus on egg production, 584 fertility, hatchability and mortality rate in chickens. Nor. Vet. Med. 28, 368-376.

585

586 Bisgaard, M., Dam, A., 1981. Salpingitis in poultry II: prevalence, bacteriology and 587 possible pathogenesis in egg laying chickens. Nord. Vet. Med. 33, 81-89.

588

589

BPC. 2016. The BPC antibiotic stewardship scheme: leading the way in the

responsible use of antibiotics. British Poultry Council. April 2016.

591

http://www.britishpoultry.org.uk/wp-

592

content/uploads/2016/04/The BPC Antibiotic Stewardship Scheme April2016.pdf

593

(accessed May 2016)

594

595

Burton, R.W., Sheridan, A.K., Howlett, C.R., 1981. The incidence and importance of tibial dyschondroplasia to the commercial broiler industry in Australia. Brit. Poultry Sci. $22,153-60$.

598

Camacho-Fernandez, D., Lopez, C., Avilla, E., Arce, J., 2002. Evaluation of different dietary treatments to reduce ascites syndrome and their effects on corporal characteristics in broiler chickens. J. Appl. Poultry Res. 11, 164-174.

602

Christensen, J-.P. (2016) Personal Communication. 
Cengiz, O., Hess, J.B., Bilgili, S.F., 2011. Effect of bedding type and transient wetness

Cook, J.K.A., Orbell, S.J., Woods, M.A., Huggins, M.B., 1999. Breadth of protection of 609 the respiratory tract provided by different live-attenuated infectious bronchitis vaccines against challenge with infectious bronchitis viruses of heterologous serotypes. Avian Path. 28, 477-485.

612

Craig, J.V., Lee, H.Y., 1990. Beak trimming and genetic stock effects on behavior and mortality from cannibalism in white leghorn-type pullets. Appl. Anim. Behav. Sci. 25, 107-123.

616

de Jong, I.C., Gunnink, H., van Harn, J., 2014. Wet litter not only induces footpad dermatitis but also reduces overall welfare, technical performance and carcass yield in broiler chickens. J. Appl. Poultry Res. 23, 51-58.

620

621

622

European Commission (2015) World food consumption patterns - trends and drivers.

623 EU Agricultural Markets Briefs, No. 6, June 2015.

https://ec.europa.eu/agriculture/markets-and-prices/market-briefs en

Edwards, H.M., 1990. Efficacy of several vitamin D compounds in the prevention of tibial dyschondroplasia in broiler chickens. J. Nutr. 120, 1054-1061.

628

629 Edwards, H.M., Sorenssen, P., 1987. Effect of short fasts on the development of tibial dyschondroplasia in chickens. J. Nutr. 117, 194-200. 
632 EFSA, 2010. Scientific opinion on the influence of genetic parameters on the welfare

633 and the resistance to stress of commercial broilers. EFSA J. 8, 1666.

634

635 EFSA (European Food Safety Authority) and ECDC (European Centre for Disease

636 Prevention and Control), 2016. The European Union summary report on antimicrobial

637 resistance in zoonotic and indicator bacteria from humans, animals and food in 2014.

638 EFSA J. 14, 4380.

639

640 Ekstrand, C, Algers, B., Svedberg, J., 1997. Rearing conditions and foot-pad dermatitis 641 in Swedish broiler chickens. Prev. Vet. Med. 31, 167-174.

642

643 El-Lethey, H., Aerni, V., Jungi, T.W., Wechsler, B., 2000. Stress and feather pecking in 644 laying hens in relation to housing conditions. Brit. Poultry Sci. 41, 22-28.

645 EUROSTAT, 2016. http://ec.europa.eu/eurostat/statistics-

646 explained/index.php/Agricultural accounts and prices (accessed: August 2016).

647

648 EU, 2011. EU Action plan against the rising threats from antimicrobial resistance, $649 \operatorname{COM}(2011) 748$.

650 http://ec.europa.eu/dgs/health consumer/docs/communication amr 2011748 en.pdf 651 (accessed May 2016).

652

653 FDA, 2005.

654 http://www.fda.gov/AnimalVeterinary/SafetyHealth/RecallsWithdrawals/ucm042004.htm 655 (accessed May 2016).

656

657 Follet, G., 2000. Antibiotic resistance in the EU - science, politics, and policy.

658 AgBioForum. 3, 148-155.

659 
660 FAO, 2016a. Livestock in the balance, change in the livestock sector.

661 http://www.fao.org/docrep/005/y4252e/y4252e07.htm (accessed May 2016).

662

663

FAO, 2016b. http://faostat.fao.org/site/610/DesktopDefault.aspx?PagelD=610\#ancor

664 (accessed 25.05.16).

665

666

FAO, 2016c. http://www.fao.org/docrep/005/y4252e/y4252e07.htm (accessed

667

25.05.16).

668

669

Faramarzi, S., Bijanzad, P., Javaherzadeh, V., Moomivand, H., Stabraghi, E., Dehnavi,

670

E.N., Ghaedi, A., Zarghami, A., 2014. Evaluation of two different infectious bronchitis

671

vaccination programmes in broiler breeder chickens. Int. J. Biosci. 5, 210-216.

672

673 Fossum, O., Hansson, D.S., Engelsen Etterlin, P. and Vagsholm, I., 2009. Causes of

674 mortality in laying hens in different housing systems in 2001 to 2004 . Acta Vet. Scand.

$67551,3$.

676

677 Glatz, P.C., 2001. Effect of poor feather cover on feed intake and production of aged

678

laying hens. Asian-Australian J. Anim. Sci. 14, 553-558.

679

680 Gocsik, E., Kortes, H.E., Oude Lansink, A.G.J.M., Saatkamp, H.W., 2014. Effects of

681 different broiler production systems on health care costs in the Netherlands. Poultry

682 Sci. 93, 1301-1317.

683

684 Gregersen, R.H., Christensen, H., Ewers, C., Bisgaard, M., 2010. Impact of

685 Escherichia coli vaccine on parent stock mortality, first week mortality of broilers and

686 population diversity of E. Coli in vaccinated flocks. Avian Pathol. 39, 287-295. 
688

689

690

691

692

693

694

695

696

697

698

699

700

701

702

703

704

705

706

707

708

709

710

711

712

713

714

715

Hagger, C, Marguerat, C., Steiger-Stafl, D., Stranzinger, G., 1989. Plumage condition, feed consumption and egg production relationships in laying hens. Poultry Sci. 68, 221225.

Havenstein, G.B., Ferket, P.R., Qureshi, M.A., 2003. Growth, livability, and feed conversion of 1957 versus 2001 broilers when fed representative 1957 and 2001 broiler diets. Poultry Sci. 82, 1500-8.

Havenstein, G.B., Ferket, S.E., Scheideler, S.E., Larson, B.T., 1994. Growth, livability and feed conversion of 1957 vs 1991 broilers when fed 'typical' 1957 and 1991 broiler diets. Poultry Sci. 73, 1875-1794.

Hassanzadeh, M., Gilanpour, H., Charkkar, S., Buyse, J., Decuypere, E., 2005.

Anatomical parameters of cardiopulmonary system in three different lines of chickens:

further evidence for involvement in ascites syndrome. Avian Pathol. 34, 1.6.

Hassanzadeh, M., Buyse, J., Decuypere, E., 2008. Further evidence for the involvement of anatomical parmeters of cardiopulmonary system in the development of ascites syndrome in broiler chickens. Acta Vet.Hung. 71, 71-80.

Ignjatovic, J., Sapats, S., 2000. Avian infectious bronchitis virus. Rev. Sci. Tech. OIE. 19, 493-508.

Izadinia, M., Nobakht, M., Khajali, F., Faraji, M., Zamani, F., Qujeq, D., Karimi, I., 2010 Pulmonary hypertension and ascites as affected by dietary protein source in broiler chickens reared in cool temperature at high altitudes. Anim. Feed Sci.Tech. 155, 194200. 
716

717

718

719

720

721

722

723

724

725

726

727

728

729

730

731

732

733

734

735

736

737

738

739

740

741

742

Jordan F.T.W., Williams, N.J., Jones, W.T., 2005. Observations on salpingitis, peritonitis and salpingoperitonitis in layer breeder flock. Vet. Rec. 157, 573-577.

Kalmar, I.D., Vanrompay, D., Janssens, G.P.J., 2013. Broiler ascites syndrome: collateral damage from efficient feed to meat conversion. Vet. J. 197, 169-174.

Khajali, F., Zamani-Moghaddam, A., Asadi-Khoshoei, E., 2007. Application of an early skip-a-day feed restriction on physiological parameters, carcass traits and development of ascites in male broilers reared under regular or cold temperatures at high altitude. Anim. Sci. 78, 159-163.

Lambton, S.L., Nicol, C.J., Friel, M., Main, D.C.J., McKinstry, C.M, Sherwin, J., Weeks, C.A., 2013. A bespoke management package can reduce levels of injurious pecking in loose-housed laying hen flocks. Vet. Rec. 172, 423.

Lee, J.T., Broussard, C., Fitz-Coy, S., Burke, P., Eckert, N.H., Stevens, S.M., Anderson, P.N., Caldwell, D.J., 2009. Evaluation of live oocyst vaccination or salinomycin for control of field-strain Eimeria challenge in broilers on two different feeding programs. J. Appl. Poultry Res. 18, 458-464.

Leeson, S., Gonzalo, J., Summers, J.D., 1995. Poultry metabolic disorders and mycotoxins. University Books, Guelph, Ontario, Canada.

Leeson, S., Morrison, W.D., 1978. Effect of feather cover on feed efficiency in laying birds. Poultry Sci. 57, 1094-1096. 
743

744

745

746

747

748

749

750

751

752

753

754

755

756

757

758

759

760

761

762

763

764

765

766

767

768

769

770

Lilburn, M.S., Lauterio, T.J., 1989. Relationships among mineral balance in the diet, early growth manipulation and incidence of tibial dyschondroplasia in different strains of meat type chickens. Poultry Sci. 68, 1263-1273.

Liverani, M., Waage, J., Barnett, T., Pfeiffer, D.U., Rushton, J., Rudge, J.W., Loevinsohn, M.E., Scoones, E., Smith, R.D., Cooper, B.S., White, L.J. Goh, S., Horby, P., Wren, B., Gundogdu, O., Woods, A., and Coker, R.J (2013) Understanding and Managing Zoonotic Risk in the New Livestock Industries. Understanding and Managing Zoonotic Risk in the New Livestock Industries. Environmental Health Perspectives, $121,873-877$.

Lovland, A., Kaldhusdal, M., 2001. Severely impaired production performance in broiler flocks with high incidence of Clostridium perfringens-associated hepatitis. Avian Pathol. $30,73-81$.

Lui, L., Tong, J., Huang, J., 1992. Effect of dietary chloride and magnesium on on the incidence of tibial dyschondroplasia in chickens fed on Chinese practical diets. Brit. Poultry Sci. 3: 603-611.

Martland, M.F., 1985. Ulcerative dermatitis in broiler chickens: the effects of wet litter. Avian Pathol. 14, 353-364.

Maxwell, M.H., Robertson, G.W., 1998. UK survey of broiler ascites and sudden death syndromes in 1993. Brit. Poultry Sci. 39, 203-215

Mayne, R.K., Else, R.W., Hocking, P.M., 2007. High litter moisture alone is sufficient to cause footpad dermatitis in growing turkeys. Brit. Poultry Sci. 48, 538-545. 
771 Medina, H.A. 2008. Factors that could indice peritonitis in commercial egg layers.

772 Zootechnica, 2 October 2008. http://www.zootecnicainternational.com/article-

773 archive/veterinary/234-factors-that-could-induce-peritonitis-in-commercial-egg-layers-

$774 \quad$ html (accessed May 2016)

775

776 Miguel, J.A., Asenjo, B., Ciria, J., del Cacho, E., Calco, J.L., 2008. Comparison of

control methods for coccidiosis in native Spanish 'Castellana Negra' chickens. Spanish

J. Agr. Res. 6, 531-536.

779

780

Miller, R.W., Skinner, E.J., Sulakvelidze, A., Mathis, G.F., Hofacre, C.L., 2010.

781

Bacteriophage therapy for control of necrotic enteritis of broiler chickens experimentally

782

infected with clostridium perfringens. Avian Dis. 54, 33-40.

783

784

Morris, M.P.,1992. Ascites in broilers. Poultry Int. October, 26-32.

785

786

Morris, M.P., 1993. National survey of leg problems. Broiler Industry 93 (May): 20-24.

787

788

Muneer, M.A., Halvorson, D.A., Sivanandan, V., Newman, J.A., and Coon, C.N.,1986.

789

Effects of infectious bronchitis virus (Arkansas strain) on laying chickens. Avian Dis. 30,

790

644-7.

791

792

Muneer, M.A., Newman, J.A., Halvorson, D.A., Sivanandan, V. and Coon, C.A., 1987.

793

Effects of Avian Infectious Bronchitis Virus (Arkansas Strain) on Vaccinated Laying

794

Chickens. Avian Dis. 31(4), 820-828.

795

796

Muneer, M.A., Chaudhry, K.M. and Khawaja, K.M., 2000. Losses due to infectious

797

bronchitis virus infection in laying and breeding hens. Pakistan Vet. J. 20, 64-70. 
799

800

801

802

803

804

805

806

807

808

809

810

811

812

813

814

815

816

817

818

819

820

821

822

823

824

825

826

Nahashon, S.N., Nakaue, H.S. and Mirosh, L.W., 1996. Performance of single comb white Leghorn fed a diet supplemented with a live microbial during the growth and egg laying phases. Anim. Feed Sci. Tech. 57, 25-38.

Narrod, C., Tiongco, M. and Costales, A., 2008. Global poultry sector trends and external drivers of structural change.

http://www.fao.org/AG/againfo/home/events/bangkok2007/docs/part1/1 1.pdf (accessed 25 May, 2016).

National Chicken Council, (2016) http://www.nationalchickencouncil.org/about-theindustry/statistics/u-s-broiler-performance/ (accessed19.05.16).

Nasr, M.A.F., Murrell, J., Wilkins, L.J., Nicol, C.J., 2012. The effect of keel fractures on egg-production parameters, mobility and behaviour in individual laying hens. Anim. Welfare 21, 127-135.

Nasra, M.A.F., Murrella, J., Nicol, C.J., 2013. The effect of keel fractures on egg production, feed and water consumption in individual laying hens. Brit. Poultry Sci. 54, 165-170.

Nicol, C.J., Gregory, N.G., Knowles, T.G., Parkman, I.D.,Wilkins, L.J., 1999. Differential effects of increased stocking density, mesiated by increased flock size, on feather pecking and aggression in laying hens. Appl. Anim. Behav. Sci. 65, 137-152.

Onbasilar, E.E., Erol, H. Cantekin, Z., Kaya, U.,2007. Influence of intermittent lighting on broiler performance, incidence of tibial dyschondroplasia, tonic immobility, some blood parameters and antibody production. Asian-Australian J. Anim. Sci. 20, 550-555. 
827 Pagazaurtundua, A., Warriss, P.D., 2006. Levels of foot pad dermatitis in broiler

828 chickens reared in 5 different systems. Brit. Poultry Sci. 47, 529-535.

829

830 Peguri, A., Coon, C., 1993. Effect of feather coverage and temperature on layer

831 performance. Poultry Sci. 72, 1318-1329.

832

833 Petek, M. Sonmez, G., Yildiz, H., Baspinar, H., 2005. Effects of different management

834 factors on broiler performance and incidence of tibial dyschondroplasia. Brit. Poultry

835 Sci. 46, 16-21.

836

837 Petrik, M.T., Guerin, M.T., Widowski, T.M., 2015. On-farm comparison of keel fracture

838 prevalence and other welfare indicators in conventional cage and floor-housed laying

839 hens in Ontario, Canada. Poultry Sci. 94, 579-585.

840

841 Reid, G. and Bocking, A., 2003. The potential for probiotics to prevent bacterial

842 vaginosis and preterm labor. Am. J. Obstet. Gynecol. 189, 1202-8.

843

844 Rincon, M.U., 2000. Mild feed restriction and compensatory growth in the broiler

845 chicken. MSc thesis, University of Guelph, Guelph, Canada.

846

847 RSPCA, 2015. Laying hens - farming (egg production).

848 http://www.rspca.org.uk/adviceandwelfare/farm/layinghens/farming (accessed

849 19.05.16).

850

851 RSPCA (2016) http://www.rspca.org.uk/adviceandwelfare/farm/layinghens/farming

$852 \quad$ (accessed 19.05.16). 
854 Rural Business Research (RBR), 2014. Poultry production in England: Farm Business

855 Survey 2012/13. Crane, R., Davenport, R., Laney, S., Vaughan, R. RBR, February

8562014.

857

858 Sherwin, C.M., Richards, G.J., Nicol, C.J., 2010. Comparison of the welfare of layer

859 hens in 4 housing systems in the UK. Brit. Poultry Sci. 51, 488-499.

860

861 Shini S., Shini, A., Blackall, P J., 2013. The potential for probiotics to prevent

862 reproductive tract lesions in free-range laying hens. Anim. Prod. Sci. 53, 1298-1308.

863

864 Shirley, M.W., Bushell, A.C., Bushell, J.E., McDonald, V., Roberts, B., 1995. A live

865 attenuated vaccine for the control of avian coccidiosis: trials in broiler breeders and

replacement layer flocks in the UK. Vet. Rec. 137, 453-457.

867

Sou, X., Zhang, J.X., Li, Z.G., Yang, C.T., Min, Q.R., Xu, L.T., Lui, Q. And Zhu, X.Q.,

2006. The efficacy and economic benefits of Supercox®, a live anticoccidial vaccine in

872 Swayne, D.E., 2013. Diseases of poultry, 13th ed, in: Swayne, D.E. (Ed.), Glisson,

873 J.R., McDougald, L.R., Nolan, L.K., Suarez, D.L., Nair, V. (Associate Eds.), Wiley-

874 Blackwell, New York, USA.

875

Sykes, R., 2010. The 2009 Garrod lecture: the evolution of antimicrobial resistance: a

Darwinian perspective. J. Antimicrob. Chemoth. 65, 1842-52.

878

879 Tactacan, G.B., Schmidt, J.K., Miille, M.J., Jimenez, D.R., 2013. A Bacillus subtilis 880 (QST 713) spore-based probiotic for necrotic enteritis control in broiler chickens. J. 881 Appl. Poultry Res. 22, 825-831. 
883 Taira, K, Nagai, T., Obi, T., Takase, K., 2013. Effect of litter moisture on the

884 development of footpad dermatitis in broiler chickens. J. Vet. Med. Sci. 76, 583-586.

885

886

Tarpey, I., Orbell, S.J., Britton, P., Casais, R., Hodgson, T., Lin, F., Hogan, E.,

887

Cavanagh, D., 2006. Safety and efficacy of infectious bronchitis virus used for chicken embryo vaccination. Vaccine $24,6830-6838$.

889

890

Tawfik, H.I., Salama, E., Hassan, O.M., Ahmed, A.,2013. Preparation and evaluation of 891 live bivalent bronchitis vaccine in chicken. Researcher 5, 31-35.

892

893

Thøfner, I., Ladefoged Poulsen, L., Bisgaard, M., Christensen, H., Heidemann Olsen, 894 R., Christensen, J.P., 2015. Longitudinal study of mortality observed in four broiler breeder flocks. Paper presented at 19th WVPA Congress, Cape Town, 7-11.11.15.

Trablante, N.L. Estevez, I., Russek-Cohen, E., 2003. Effect of perches and stocking 898 density on tibial dyschondroplasia and bone mineralization as measured by bone ash in broiler chickens. J. Appl. Poultry Res. 12, 53-59.

900

901

Traill,W. B., Mazzocchi, M., Shankar, B., Hallam, D. (2014) Importance of government 902 policies and other influences in transforming global diets. Nutrition Reviews, 72(9), $591-604$.

904

905

Vanhemelrijck, J., 1999. Risk management: from antibiotic discovery to market. Paper 906 presented at the OIE Scientific Conference, Paris, France. March, 1999.

907 
908 Van Horne P.M.L., 2014. Competitiveness of the EU egg sector: international

909 comparison base year 2013. Report LEI 2014-041. LEI Wageningen UR, Wageningen,

910 December 2014.

911

912 Van Horne, P.L.M, Bont, N., 2014. Competitiveness of the EU poultry meat sector:

913 International comparison base year 2013. LEI Report 2013-068, LEI Wageningen UR,

914 The Hague, December, 2013.

915

916 Vits, A., Weitzenburger, D., Hamann, H., Distl, O., 2005. Production, egg quality, bone

917 strength, claw Length, and keel bone deformities of laying hens housed in furnished

918 cages with different group sizes. Poultry Sci. 84, 1511-1519.

919

920 Wang, G. Ekstrand, C., Svedberg, J., 2010. Wet litter and perches as risk factors for

921 the development of footpad dermatitis in floor-housed hens. Brit. Poultry Sci. 39, 191-

922197.

923

924 Vermeulen, A.N., Schaap, D.C., Schetters, T.P., 2001. Control of coccidiosis in

925 chickens by vaccination. Vet. Parasitol. 100, 13-20.

926

927 Wilkins, L.J., McKinstry, J.L., Avery, N.C., Knowles, T.G., Brown, S.N., Tarlton, J., 928 Nicol, C.J., 2011. Influence of housing system and design on bone strength and keel 929 bone fractures in laying hens. Vet. Rec. 169, 414.

930

931

Williams, R.B., 1998. Anticoccidial vaccines for broiler chickens: pathways to success.

Avian Pathol. 31, 317-353.

Williams, R.B., 1999. A compartmentalised model for the estimation of the cost of coccidiosis to the world's chicken production industry. Int. J. Parasitol. 29, 1209-1229. 
937 Williams, R.B., Carlyle. W.W., Bond, D.R., Brown, I.A., 1999. The efficacy and

938 economic benefits of Paracox, a live attenuated anticoccidial vaccine, in commercial

939 trials with standard broiler chickens in the UK. Int. J. Parasitol. 29, 341-355

940

941 Williams, R.B., Gobbi, L., 2002. Comparison of an attenuated anticoccidial vaccine and

942 an anticoccidial drug programme in commercial broiler chickens in Italy. Avian Pathol.

$943 \quad 31,253-265$.

944

945 Willis, W.L., Read, L., 2008. Investigating the effects of dietary probiotic feeding

946 regimens on broiler chicken production and Campylobacter jejuni presence. Poultry

947 Science 87: 606-611.

948

949 Yalcin, S., Molayoglu, H.B., Baka, M., Genin, O., Pines, M., 2007. Effect of temperature 950 during the incubation period on tibial growth plate chondrocyte differentiation and the 951 incidence of tibial dyschondroplasia. Poultry Sci. 86, 1772-1783.

952

953 Zhang, G., Mathis, G.F., Hofacre, C.L., Yaghmaee, P., Holley, R.A., Duranc, T.D., 954 2010. Effect of a radiant energy-treated lysozyme antimicrobial blend on the control of 955 clostridial necrotic enteritis in broiler chickens. Avian Dis. 54, 1298-1300. 


\begin{tabular}{|c|c|c|}
\hline & Broilers & Layers \\
\hline Sales: & $\begin{array}{l}\text { Revenues }(€ / 100 \\
\text { kg live weight) }{ }^{6}\end{array}$ & $\begin{array}{l}\text { Revenues }(€ I \\
\text { hen) }{ }^{6}\end{array}$ \\
\hline $\begin{array}{l}\text { Broilers, }(2.276 \mathrm{~g} \text { of meat per bird } \\
\text { at } € 107.7 / 100 \mathrm{~kg} \text { liveweight); } \\
\text { Layers, } 340 \text { eggs at } € 7.6 / 100 \\
\text { eggs }{ }^{7}\end{array}$ & 107.7 & 25.84 \\
\hline Spent hens & - & 0.36 \\
\hline Expenditure: & $\begin{array}{l}\text { Production costs } \\
\text { ( } € / 100 \text { kg live } \\
\text { weight) }{ }^{10}\end{array}$ & $\begin{array}{l}\text { Production costs } \\
\text { ( } € \text { / hen })^{8,9}\end{array}$ \\
\hline $\begin{array}{l}\text { Day old chicks / pullets (17 } \\
\text { weeks) }\end{array}$ & 15.20 & 3.30 \\
\hline Mortality $^{1}$ & 2.02 & 0.87 \\
\hline Feed & 67.00 & 10.29 \\
\hline Medication, 5 & 1.40 & $0.09^{4}$ \\
\hline Heating and electricity & 2.20 & \multirow{3}{*}{$1.41^{4}$} \\
\hline Water & 0.60 & \\
\hline Litter (incl. cleanout \& disposal) & 3.70 & \\
\hline Labour & 3.40 & 1.10 \\
\hline Housing ${ }^{2}$ & 6.40 & 2.75 \\
\hline General $^{3}$ & 1.00 & 0.41 \\
\hline Total costs & 102.92 & 20.22 \\
\hline Net margin & 4.74 & 5.98 \\
\hline
\end{tabular}

958

$959{ }^{1}$ Mortality costs assumed to be $50 \%$ of total rearing costs per dead bird. Mortality rate 960 for layers assumed to be $9 \%$.

$961{ }^{2}$ Housing costs includes: poultry house and inventory.

$962{ }^{3}$ General costs include: insurance, office, consultancy, telephone, transport.

$963{ }^{4}$ Medication, heating and electricity, water and litter costs are equated with the 'Other 964 variable costs' category of Van Horne (2014), which includes: heating, electricity, litter, 965 animal health and catching.

$966{ }^{5}$ Medication costs for broilers taken from Cocsik et al. (2014); layers from RBR (2014).

$967{ }^{6} 2013$ broiler meat and egg prices; Eurostat Median of EU28 prices (authors' own 968 calculations)

http://ec.europa.eu/eurostat/statistics- 
$971{ }^{7}$ Number of eggs produced per housed bird $=340$ (source: van Horne, 2014), based

972 on enriched cage system).

$973{ }^{8}$ Sources: Van Horne (2014); Agro-Business Consultants Ltd (2012); RBR (2014).

97492013 prices (based on 2010 (Van Horne, 2014) prices adjusted for inflation using

975 annual GDP deflators for the EU. Source: World Bank National Accounts Data \& OECD

$976 \quad$ National Accounts files 2010-2015)

$977{ }^{10}$ Sources: Van Horne (2014); Agro-Business Consultants Ltd (2012).

978 